
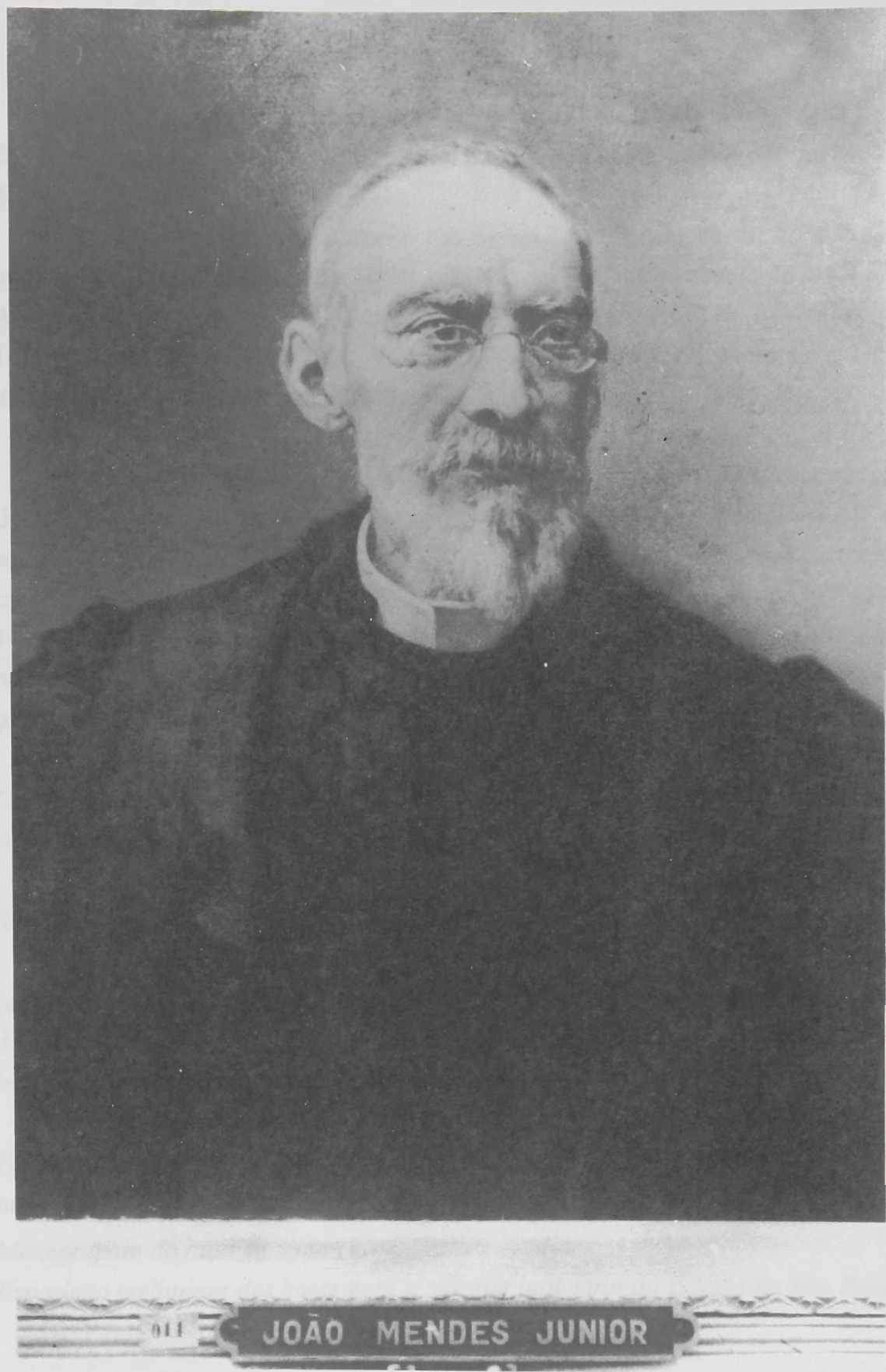



\section{Dr. JOÃO MENDES DE ALMEIDA JUNIOR}

(1912-1915)

Filho do jurisconsulto e político Dr. João Mendes de Almeida e de D. Anna Rita Lobo Mendes de Almeida, nasceu na cidade de São Paulo, aos 30 de março de 1856.

Feitos os preparatórios no Seminário Episcopal de São Paulo, matriculou-se na Faculdade de Direito de São Paulo, bacharelando-se em 1877. Aprovado em defesa de teses, recebeu o grau de doutor em 2 de novembro de 1879. No ano seguinte foi eleito vereador municipal, servindo como presidente da Câmara Municipal nos anos de 1881 a 1882.

Militou na imprensa.

Aprovado em concurso, foi nomeado lente substituto da Faculdade de Direito, por decreto de 31 de agosto de 1889, tomando posse aos 10 de setembro desse ano. Por decreto de 21 de março de 1891, foi nomeado lente catedrático de prática forense, quarta cadeira da quarta série de Ciências Jurídicas, da qual tomou posse a 10 de abril seguinte. Por decreto de 7 de fevereiro de 1896, foi designado para reger a primeira cadeira de teoria do processo civil comercial e criminal, e prática forense.

Em execução a lei orgânica de 1911, eleito diretor, em Congregação, em sessão de 29 de novembro de 1912, para o biênio 1913-14, exerceu o cargo até 7 de abril de 1915.

Por decreto de 11 de dezembro de 1916, foi nomeado ministro do Supremo Tribunal Federal, tomando posse a 5 de janeiro de 1917.

Faleceu aos 25 de fevereiro de 1923. Foi um dos maiores jurisconsultos brasileiros. Em homenagem aos seus grandes méritos, o Instituto da Ordem dos Advogados de São Paulo ofereceu à Faculdade de Direito o seu busto em bronze, que se acha no seu Salão Nobre.

Além dos inúmeros trabalhos, que publicou na Revista $d a$ Faculdade de Direito de São Paulo, deixou as seguintes obras clássicas no direito nacional:

Monographia do municipio da cidade de São Paulo.

Exposição preliminar das bases para a reforma judiciaria do Estado de São Paulo.

São Paulo : Espindola, Siqueira \& Cia., 1901. 
As formas organicas da praxe forense.

O processo criminal brasileiro. 2 vs.

Programa do curso de direito judiciario, lecionado na Faculdade de Direito de São Paulo. São Paulo : Hennies Irmãos, 1910. Teve $2^{a}$ edição argumentada em 1918.

Plano de refórma judiciaria, submetido ao Congresso Legislativo do Estado de São Paulo pelo Dr. Francisco de Paula Rodrigues Alves, presidente do mesmo Estado. São Paulo: Siqueira, 1912. 3 vs.

Golpes de retrospecto: preleç̧ão de abertura da aula da primeira cadeira do quinto anno da Faculdade de Direito de S. Paulo. São Paulo : Hennies Irmãos, 1913. O ensino do direito. São Paulo : Siqueira, 1914.

A uniformidade, a simplicidade e a economia do nosso processo forense. São Paulo : Siqueira, 1915.

Os indigenas do Brasil, seus direitos, individuaes e politicos.

Climax ou escada do céu. (obra de São João Climaco, que poz em vernáculo). 